PAEDAGOGIA ChRISTIANA

I/21 (2008) - ISSN 1505-6872

Jarostaw Horowski*

Toruń

\title{
Pedagogika tomistyczna a pedagogika wartości
}

Temat wartości postrzegany jest $\mathrm{w}$ refleksji pedagogicznej jako istotny, ponieważ aksjologia rozumiana jest jako podstawa formułowania teleologii wychowania $^{1}$. Obecne zainteresowanie tematem wartości ma związek z problemami, jakie generuje kultura przełomu XX i XXI wieku - kultura postmodernistyczna. Nie analizując aksjologicznego przesłania różnych koncepcji filozoficznych, które wywarły wpływ na tworzenie postmodernizmu, należy stwierdzić, że popularna wersja tego nurtu rodzi trudności w zakresie określenia wartości podstawowych i sensu własnej egzystencji oraz w zakresie realizacji wartości w życiu indywidualnym i społecznym ${ }^{2}$. Postmodernizm w wersji popularnej charakteryzuje się bowiem: skrajnie liberalną interpretacją wolności, zmierzającą często w kierunku mieszania wolności ze swobodą; odrzuceniem normatywności, co objawia się między innymi zastapieniem pojęcia prawdy terminem poglad; oraz wezwaniem do tolerancji odmiennych poglądów i postaw - tolerancji pojawiającej się w wyniku zakwestionowania obiektywnego charakteru dobra i zła ${ }^{3}$. W kontekście problemów, generowanych przez kulturę postmodernistyczną, mówi się więc często o potrzebie wartości, wychowania do wartości czy wychowania do urzeczywist-

* Dr Jarosław Horowski, adiunkt w Wydziale Nauk Pedagogicznych UMK w Toruniu.

${ }^{1}$ Por. M. Nowak, Podstawy pedagogiki otwartej, Lublin 2000, s. 421-422.

${ }^{2}$ Por. J. Michalski, Edukacja i religia jako źródła rozwoju egzystencjalno-kognitywnego. Studium hermeneutyczno-krytyczne, Toruń 2004, s. 14, 23-25.

${ }^{3}$ Por. Z. Sareło, Postmodernistyczny styl myślenia $i$ życia, w: tenże (red.), Postmodernizm. Wyzwanie dla chrześcijaństwa, Poznań 1995, s. 10; A. Szahaj, Co to jest postmodernizm?, Ethos 9 (1996), nr 33-34, s. 72; S. Kowalczyk, Idee filozoficzne postmodernizmu, Radom 2004, s. 37; A. Bronk, Krajobraz postmodernistyczny, Ethos 9 (1996), nr 33-34, s. 84. 
niania wartości ${ }^{4}$, a w następstwie każdej tragedii, wywołanej złą wolą człowieka, pojawia się stwierdzenie o braku wartości w rodzinie, szkole, społeczeństwie. Podejmuje się również próby określenia wartości podstawowych, które powinny być realizowane przez wszystkich. Głos w tej dyskusji zabiera myśl chrześcijańska, wysuwając propozycję zhierarchizowanego systemu wartości i sugerując, że zaakceptowanie go przyczyniłoby się do przezwyciężenia obecnego kryzysus ${ }^{5}$. Analiza koncepcji pedagogicznych, których autorzy deklarują religijne odniesienia, wskazuje jednak na brak wspólnego stanowiska w omawianej kwestii. Z jednej strony, w ramach dyskursu w nurcie personalizmu mówi się o doskonaleniu osoby poprzez przyjmowanie i urzeczywistnianie wartości, a z drugiej strony, wypowiedzi odwołujące się do zasad tomistycznych pomijają kwestię wartości w wychowaniu albo zaprzeczają możliwości wychowania poprzez przekaz wartości.

Brak jednoznacznego stanowiska $\mathrm{w}$ podejściu do wartości rodzi pytanie o przyczyny takiego stanu i skłania do spojrzenia na zagadnienie wartości w wychowaniu z różnych perspektyw. Naszkicowanie różnic między tymi perspektywami i zrozumienie argumentów, powodujących różne stanowiska w kwestii wartości, nie przyczyni się z pewnością do przezwyciężenia sprzeczności, które wynikają z różnych założeń ontologicznych i epistemologicznych przywołanych nurtów ${ }^{6}$. Głębsza analiza może jednak ukazać, co wnoszą poszczególne ujęcia w rozumienie procesu wychowania oraz jakie słabe strony zawierają. Po kolei poszukiwane będą więc odpowiedzi na pytania: na czym polega wychowanie do wartości?; jaką alternatywę dla wychowania do wartości przedstawia myśl tomistyczna?; oraz jakie zalety oraz wady posiadają poszczególne ujęcia?

\section{Specyfika wychowania do wartości}

Nie sposób mówić o wychowaniu do wartości bez wstępnej odpowiedzi na pytanie, czym jest wartość. Mimo powszechnego użycia pojęcia wartość, jego zdefiniowanie nie jest łatwe. Sam termin, początkowo używany przede wszystkim w działalności gospodarczej, został zastosowany w filozofii stosunkowo niedawno. Posłużył się nim w swoim systemie Immanuel Kant, ale spopularyzował go dopiero pod koniec XIX wieku Fryderyk Nietzsche, głosząc przewartościowanie wszystkich wartości. Wcześniej w refleksji filozoficznej posługiwano się

${ }^{4}$ Zob. B. Żurakowski, Wychowanie do wyboru wartości, w: F. Adamski (red.), Wychowanie personalistyczne. Wybór tekstów, Kraków 2005, s. 279-290; K. Ostrowska, Wychowywać do urzeczywistniania wartości, w: F. Adamski (red.), dz. cyt., s. 291-308.

${ }^{5}$ Por. H. Gajdamowicz, Wychowanie chrześcijańskie w perspektywie obiektywistycznych teorii wartości, w: A. Rynio (red.), Wychowanie chrześcijańskie między tradycjq a wspótczesnościa, Lublin 2007, s. 103.

${ }^{6}$ Por. W. Stróżewski, Istnienie i wartość, Kraków 1981, s. 67-68. 
jedynie pojęciem dobra. Nie tyle jednak niedługa historia terminu wartość powoduje trudności w sformułowaniu jego definicji, co fakt, że problem wartości podejmowany jest $w$ różnych nurtach filozoficznych i każda odpowiedź na pytanie o naturę wartości wynika przede wszystkim z ogólno-filozoficznych założeń stanowiska, w ramach którego jest budowana ${ }^{7}$.

Unikając podawania definicji, co wiązałoby się z wyborem określonej koncepcji filozoficznej, należy stwierdzić, że o wartościach mówi się w sensie przedmiotowym i podmiotowym. Zauważa się bowiem, że wartość jest związana z czymś i z kimś. Różne koncepcje wartości sytuują się między biegunami przedmiotowym i podmiotowym. Założenie istnienia wartości, niezależnego od aktu poznawczego człowieka, czyli związanie wartości z przedmiotem, prowadzi do przyjęcia obiektywistycznej koncepcji wartości, natomiast stwierdzenie, że wartości są konstruowane przez podmiot i nadawane poszczególnym rzeczom jest równoznaczne z zajęciem stanowiska subiektywistycznego ${ }^{8}$. Implikacją subiektywizmu jest relatywizm wartości, a obiektywizm skutkuje absolutyzowaniem wartości.

W historii filozofii pojawiały się zarówno koncepcje subiektywistycznorelatywistyczne, jak i stanowiska obiektywistyczno-absolutystyczne. Subiektywizm głosili m.in. przywołani już Kant oraz Nietzsche, a także Moritz Schlick i Martin Heidegger. Do obrońców obiektywizmu wartości zalicza się Maxa Schelera, Nicolai Hartmanna oraz Dietricha von Hildebranda, rozwijających nurt fenomenologii ${ }^{9}$. Kant wyszedł z założenia, że rozum nie może poznawczo osiagnąć dziedziny bytu. Podważenie wartości aktów poznawczych sprawiło, że poszukując oparcia dla etyki, uznał on, iż rozum praktyczny formułuje imperatywy kategoryczne, które nakazują woli konkretny uczynek. W tej koncepcji wartość rozumiana była jako korelat intencjonalnego aktu woli, więc miała charakter podmiotowy ${ }^{10}$. Scheler wypracował swoją filozofię i etykę kwestionując koncepcje Kanta. Stanął na stanowisku, że człowiek zastaje wartości w świecie. Są one bytami idealnymi, ponadczasowymi, niezmiennymi. Mają więc charakter obiektywny. Człowiek nie określa ich, tylko je odkrywa. Scheler odrzucił relatywizację wartości zarówno wobec indywiduów ludzkich, jak i względem systemów kulturowych czy społecznych ${ }^{11}$. Według niego, wartości dzielą się na hedonistyczne, witalne, duchowe i religijne oraz istnieje między nimi obiektywna, rozpoznawana

${ }^{7}$ Por. A. B. Stępień, Aksjologia, w: J. Herbut (red.), Leksykon filozofii klasycznej, Lublin 1997, s. 23-24; M. A. Krąpiec, Odzyskać świat realny, Lublin 1993, s. 322; W. Stróżewski, Filozofia wartości, Znak 17 (1965), z. 4, s. 400; tenże, Istnienie..., s. 20-21.

${ }^{8}$ Por. T. Czeżowski, Czym sq wartości?, Znak 17 (1965), z. 4, s. 408; W. Stróżewski, Istnienie..., s. 24-25.

${ }^{9}$ Por. S. Kowalczyk, Człowiek w poszukiwaniu wartości. Elementy aksjologii personalistycznej, Lublin 2006, s. 135-137; J. Galarowicz, Fenomenologiczna etyka wartości, Kraków 1997, s. 30-31; H. Gajdamowicz, dz. cyt., s. 109-111.

${ }^{10}$ Por. M. A. Krąiec, Odzyskać świat realny, Lublin 1993, s. 325.

${ }^{11}$ Por. J. Galarowicz, dz. cyt., s. 55, 79; W. Stróżewski, Istnienie..., s. 26. 
w doświadczeniu hierarchia. Teoria wartości stała się w fenomenologii podstawą etyki, która miała być obiektywna i powszechnie obowiązująca ${ }^{12}$. Odwołując się do myśli Schelera, również inni fenomenologowie określili wartości jako idee, istniejące niezależnie od rzeczy ${ }^{13}$.

We wstępie powiedziane zostało, że temat wartości podejmowany jest m.in. w pedagogice personalistycznej. Stwierdzenie to jest jednak dużym uproszczeniem z dwóch względów. Po pierwsze, personalizm jest raczej ruchem niż konkretnym kierunkiem i jego idee można odnaleźć m.in. w koncepcjach opartych na fenomenologii, egzystencjalizmie, neotomizmie, augustynizmie ${ }^{14}$. Po drugie, w pracach omawiających pedagogikę personalistyczną, ich autorzy posługują się najczęściej koncepcją wartości, wypracowaną przez fenomenologię ${ }^{15}$. Na gruncie polskim myśl Schelera podjęta została przez Romana Ingardena, wywarła też wpływ na Karola Wojtyłę. Dzięki nim przyczyniła się z kolei do nakreślenia kształtu personalizmu w Polsce ${ }^{16}$. Propagatorem tez fenomenologii, a wśród nich twierdzenia, że ludzkie myślenie jest myśleniem wedtug wartości, był również Józef Tischner. Uważał on, że świat, w którym żyje człowiek, jest światem wartości, czyli zawiera coś, co jest dobre, i coś, co jest złe, a także coś, co jest lepsze, gorsze, najgorsze. Postrzegał świat jako hierarchicznie uporządkowany i był przekonany, że hierarchia wartości tworzy ład w świecie. Samego człowieka rozumiał jako istotę czytającą wartości, mimo że nie potrafi on zdefiniować dobra i zła oraz ustalić precyzyjnej granicy między jednym i drugim ${ }^{17}$.

Koncepcje pedagogiczne, odwołujące się do wartości, mówiące o wychowaniu, posługują się sformułowaniem, że fundament dla niego tworzą wartości. Poprzez przyswajanie wartości, człowiek aktualizuje bowiem samego siebie, dochodzi do swej pełni ${ }^{18}$. Skoro przyswajanie wartości jest konieczne dla rozwoju człowieka, to celem wychowania jest pomoc dojrzewającemu człowiekowi w odkrywaniu i introcepcji wartości. Chodzi o to, aby wychowanek zetknął się z wartością, doświadczył jej, a następnie nauczył się urzeczywistniania wartości przedmiotowych: materialnych, społecznych, kulturalnych, duchowych, religijnych, aby posiadł zdolność wyboru wartości oraz umiejętność poruszania się W świecie wartości ${ }^{19}$.

\footnotetext{
${ }^{12}$ Por. W. Tatarkiewicz, Historia filozofii, t. 3, Warszawa 1995, s. 215, 220-221.

${ }^{13}$ Por. J. Herbut, Dobro, w: tenże (red.), dz. cyt., s. 116-117; W. Stróżewski, W kręgu wartości, Kraków 1992, s. 58-59.

${ }^{14}$ Por. M. Nowak, Pedagogika personalistyczna, w: Z. Kwieciński, B. Śliwerski (red.), Pedagogika. Podręcznik akademicki, t. 1, Warszawa 2005, s. 237-238.

${ }^{15}$ Por. M. Gogacz, Osoba zadaniem pedagogiki. Wyktady bydgoskie, Warszawa 1997, s. 40.

${ }^{16}$ Por. J. Galarowicz, dz. cyt., s. 118.

${ }^{17}$ Por. J. Tischner, Myślenie wedlug wartości, Kraków 2000, s. 479-480.

${ }_{18}$ Por. Z. Matulka, Wartości u podstaw wychowania personalistycznego, w: F. Adamski (red.), dz. cyt., s. 225; W. Stróżewski, $W$ kręgu..., s. 38.

${ }^{19}$ Por. M. Nowak, Znaczenie wartości w procesie wychowania, w: K. Popielski (red.), Człowiek - wartości - sens. Studia z psychologii egzystencji, Lublin 1996, s. 254; J. Homplewicz,
} 
Punktem wyjścia w procesie rozwoju poprzez przyswajanie wartości jest odkrycie wartości. Teorie aksjologiczne określają je jako funkcję intuicji lub łączą $\mathrm{z}$ doświadczeniem emocjonalnym ${ }^{20}$. Intuicja $\mathrm{w}$ potocznym rozumieniu jest przeczuciem czegoś, ewentualnie rozbłyskiem rozumienia jakiejś sytuacji lub stanu rzeczy, dokonującym się bez wnioskowania. Intuicja łączy się często z przeświadczeniem o prawdziwości poznawczego rezultatu. Na współczesne pojmowanie intuicji wpłynął znacząco Edmund Husserl, który stwierdził, że poznanie intuicyjne nie odnosi się jedynie do przedmiotów indywidualnych, ale możliwe jest intuicyjne poznanie ogółu, istoty czegoś. Teoria ta przyczyniła się z kolei do rozwoju aksjologii fenomenologicznej, według której poznanie intuicyjne odnosi się do szczególnego typu przedmiotów, jakimi są wartości ${ }^{21}$. Powiązanie doświadczenia aksjologicznego z emocjami jest zasługą Schelera. Według niego, emocje odkrywają nie tylko dostęp do wartości, ale pozwalają także uchwycić ich specyfikę i rozmaite zależności zachodzące między nimi. Stanowisko Schelera nazywane jest panemocjonalizmem. Przekonywał on, że uczucia są aktami wypełnionymi treścią i konstytuującymi sensy przedmiotowe, a nawet pozwalają docierać tam, gdzie rozum okazuje się bezsilny. Intelekt poznaje bowiem tylko rzeczy, natomiast emocje umożliwiają pełne poznanie dziedziny wartości. Przed Schelerem charakter intencjonalny przypisywano jedynie aktom intelektualnym, a sferę przeżyć emocjonalnych postrzegano jako pasywną ${ }^{22}$. Wpływ wartości na ludzkie emocje jest podkreślany na gruncie pedagogiki między innymi przez Janusza Homplewicza, który mówi, że wartości są w stanie rozbłysnać, roziskrzyć się, pochłaniać człowieka coraz bardziej, powracać i powtarzać swe nasilenia ${ }^{23}$. Marian Nowak posługuje się z kolei sformułowaniem, że posiadają moc uwodzenia człowieka ${ }^{24}$.

Doświadczenie konkretnej wartości sprawia, że człowiek musi odnieść się do niej. Wartość staje się więc przedmiotem wyboru i zaczyna tworzyć życie wewnętrzne człowieka ${ }^{25}$. Oznacza to, że wartości są w stanie wywierać kształtujący wpływ na osobę i za ich pomocą można organizować i przeprowadzać ten wpływ. Ponieważ człowiek może być pociagany przez różne wartości, zarówno egoistyczne, jak i bardzo szlachetne, altruistyczne, dlatego zadaniem wychowawcy jest pobudzanie wychowanka do rozwoju aksjologicznego. Realizacja wartości wychowawczych rozpoczyna się od samego wychowawcy, od pojawienia się u niego

Promocja etyki pedagogicznej, Paedagogia Christiana 1/5 (2000), s. 78; Z. Matulka, dz. cyt., s. 227.

${ }^{20}$ Por. W. Stróżewski, Istnienie..., s. 32.

${ }^{21}$ Por. S. Judycki, Intuicja, w: J. Herbut (red.), dz. cyt., s. 306.

${ }^{22}$ Por. J. Galarowicz, dz. cyt., s. 64, 68-72; J. Herbut, M. Żardecka, Uczucia, w: J. Herbut (red.), dz. cyt., s. 524-525; W. Tatarkiewicz, dz. cyt., t. 3, s. 215, 220-221.

${ }^{23}$ Por. J. Homplewicz, dz. cyt., s. 77.

${ }^{24}$ Por. M. Nowak, Znaczenie..., s. 254.

${ }^{25}$ Por. K. Popielski, Wartości i ich znaczenie w życiu ludzi, w: tenże (red.), dz. cyt., s. 63; Z. Matulka, dz. cyt., s. 226. 
określonej, rzeczywistej wartości. Jej zaistnienie umożliwia ukazanie i przekaz wartości. Ten ostatni element dokonuje się w wychowanku według schematu: ujrzenie, zrozumienie, fascynacja, przejęcie, nowe zaistnienie. Wprowadzanie wychowanka w świat wartości to wprowadzanie go we własny świat wychowawcy. W przekazie wartości nie wchodzą więc w grę techniki, umiejętności, metodologia, ale wspólne życie i wspólne przeżywanie określonych wartości ${ }^{26}$.

\section{Pedagogika tomistyczna pedagogiką transcendentaliów}

Tradycja scholastyczna, a zwłaszcza tomistyczna, nie podejmowała na przestrzeni wieków tematu wartości. W zamian omawiała zagadnienie transcendentaliów ${ }^{27}$. Terminu tego używało się pierwotnie w odniesieniu do pojęć. Ich istotą było przekraczanie wszystkich zakresów rzeczy, wszelkich kategorii. W tomizmie, który rozwinął najpełniejszą teorię transcendentaliów, pojęć tych wymieniano siedem: byt, rzecz, jedno, odrębne-coś, prawda, dobro, piękno. Obecnie stwierdza się, że transcendentalia to nie tylko pojęcia, ale realny sposób bytowania. Transcendentalia są tożsame $\mathrm{z}$ bytem, a różnice między nimi wynikają z różnych aktów poznania, za pomocą których ujmuje się byt ${ }^{28}$.

Wśród transcendentaliów znajdują się również prawda, dobro i piękno. Aksjologia posługuje się tymi pojęciami na określenie wartości. Mimo zastosowania tych samych terminów nie można utożsamiać transcendentaliów $\mathrm{z}$ wartościami. Transcendentalia nie są treściami oddzielonymi od samej bytowości, lecz są aspektami bytu. Jeśli byt jest przedmiotem intencjonalnych aktów intelektu i woli, jest odpowiednio prawdą i dobrem, byty przyporządkowane jednocześnie do poznania i pożądania są pięknem ${ }^{29}$. Pojęciem najbliższym wartości jest w filozofii klasycznej dobro. Rozumiane jest ono jako właściwość przedmiotu, zdolna udoskonalić kogoś lub coś i z tego względu będąca pożądaną. Dobro jest właściwością przysługującą koniecznościowo każdemu bytowi, gdyż jest zespołem treści zaktualizowanych przez istnienie ${ }^{30}$. Mimo że każdy byt jest dobrem, to dobra nie są sobie równe. W hierarchii dóbr wyróżnia się dobra: czysto materialne, biologiczne, psychiczne oraz duchowe (intelektualne, estetyczne, moralne, religijne) ${ }^{31}$.

Podkreślanie znaczenia transcendentaliów dla wychowania znalazło najbardziej wyraźne ujęcie w myśli Mieczysława Gogacza. Jako filozof, jest on przedsta-

${ }^{26}$ Por. J. Homplewicz, dz. cyt., s. 75-79.

${ }^{27}$ Por. W. Stróżewski, Filozofia..., s. 404-405.

${ }^{28}$ Por. M. A. Krąpiec, Metafizyka - ogólna teoria rzeczywistości, w: M. A. Krąpiec, S. Kamiński, Z. J. Zdybicka, A. Maryniarczyk, P. Jaroszyński, Wprowadzenie do filozofii, Lublin 1996, s. 110-111; J. Herbut, Transcendentalia, w: tenże (red.), dz. cyt., s. 522.

${ }^{29}$ Por. M. A. Krapiec, Odzyskać..., s. 328-329.

${ }^{30}$ Por. J. Herbut, Dobro..., s. 116; S. Kowalczyk, Dobro. W aspekcie bytowym, w: EK, t. 3, kol. 1374; tenże, Podstawy światopogląu chrześcijańskiego, Wrocław 1995, s. 145.

${ }^{31}$ Por. J. Herbut, Dobro..., s. 116. 
wicielem tomizmu egzystencjalnego, który sam dodatkowo określa jako konsekwent$n^{32}$. Wychowaniem Gogacz nazywa czynności, które powodują nawiązywanie przez człowieka relacji z tym, co prawdziwe i dobre, czyli z tym, co wywołuje dobre skutki w człowieku. Prawda i dobro muszą, oczywiście, zostać najpierw rozpoznane i uznane, więc w wychowaniu konieczne jest usprawnienie działań intelektu i woli do poziomu mądrości. Wychowanie ma ponadto prowadzić do zdystansowania działań vis cogitativa. Jest to zmysłowa władza konkretnego osądu, mechanicznie i bezmyślnie łącząca człowieka z czymkolwiek. Brak umiejętności rozpoznawania prawdy i dobra oraz wyboru dobra, spowodowany brakiem wychowania, skutkuje nawiązywaniem przez człowieka relacji z jakimikolwiek, niekoniecznie najlepszymi bytami ${ }^{33}$. Należy zaznaczyć, że, według Gogacza, najdoskonalszymi bytami są osoby, więc wychowanie powinno prowadzić do nawiązywania relacji z osobami i podejmowania działań chroniących relacje osobowe.

W konsekwencji stwierdzenia, że celem rozwoju człowieka jest mądrość, rodzi się pytanie o pochodzenie i charakter mądrości: co sprawia, że intelekt i wola osiagają sprawność mądrości? Gogacz wyjaśnia, że intelekt bierny odbiera i ćwiczy się w ujmowaniu bytów w ich przejawach istnienia: realności, odrębności, jedności, prawdzie, dobru, pięknie. Dla mądrości szczególnie istotne są prawda oraz dobro. Prawda i dobro bytu wyzwalają poznanie, które warunkuje mądrośćc ${ }^{4}$. Poznając dobro osób i relacji międzyosobowych, człowiek może porównać je $\mathrm{z}$ dobrem przedmiotów materialnych oraz relacji nawiązywanych z tymi przedmiotami. Gogacz przekonuje, że osoba nawiązująca podstawowe relacje z rzeczami a nie z osobami nigdy nie poznała dobra relacji osobowych, czyli nikt nie wszedł z nią w trwałą relację. Powyższe sformułowania wskazują bezpośrednio, że Gogacz w swoich koncepcjach odwołuje się do transcendentaliów, a nie do wartości. Stoi na stanowisku, że człowiek poznaje konkretny byt i jego dobro, a nie emocjonalnie lub intuicyjnie ujmuje wartości.

Mimo że w innych koncepcjach pedagogicznych, budowanych na fundamencie tomizmu, nie operuje się bezpośrednio pojęciem transcendentaliów, to niewątpliwie można w nich odnaleźć rozumienie wychowania jako odkrywania realności, odrębności, prawdy, dobra i piękna bytu oraz budowania relacji z tym, co prawdziwe i dobre. Jacek Woroniecki, autor najbardziej pełnego systemu pedagogiki tomistycznej, w swoim trzytomowym dziele Katolicka etyka wychowawcza nie wspomina o wartościach, natomiast, mówiąc o działaniu człowieka, stwierdza, że wynika ono z decyzji, która powstaje w dialogu rozumu i woli, przy czym rozum kieruje się na prawdę bytu, a wola jest pociagana przez dobro ${ }^{35}$. Na uwarunkowanie systemu Woronieckiego

${ }^{32}$ Por. M. Gogacz, Współczesne interpretacje tomizmu, Znak 15 (1963), z. 11, s. 1339-1353; tenże, Elementarz metafizyki, Warszawa 1987, s. 141-149.

${ }^{33}$ Por. tenże, Osoba ..., s. 15-17, 33, 35.

34 Por. tamże, s. 19.

${ }^{35}$ Por. J. Woroniecki, Katolicka etyka wychowawcza, Lublin 2000, t. I, s. 103-107; tenże, Nawyk czy sprawność. Centralne zagadnienie pedagogiki katolickiej, Wilno 1939, s. 16-17. 
koncepcją transcendentaliów, wskazuje również zagadnienie, które jest przez niego postrzegane jako najważniejsze w pedagogice. Według Woronieckiego wychowanie ma prowadzić do ukształtowania czterech sprawności, nazywanych inaczej cnotami kardynalnymi, a mianowicie: roztropności, sprawiedliwości, umiarkowania i męstwa. Dwie ostatnie odnoszą się do władz zmysłowych, dlatego pozostaja poza bezpośrednim zakresem zainteresowania niniejszego tematu, ale dwie pierwsze są odpowiednio sprawnościami rozumu ${ }^{36} \mathrm{i}$ woli ${ }^{37}$, czyli sprawnościami rozpoznawania prawdy i wyboru dobra.

Transcendentalia, jeżeli mają wpłynąć na decyzje podejmowane przez człowieka, musza, podobnie jak wartości, zostać najpierw rozpoznane. Głównym czynnikiem zewnętrznym, wpływającym na kształtowanie u dojrzewającego człowieka sprawności roztropności i sprawiedliwości, jest rzeczywistość, która nie pozostawia wątpliwości, co jest prawdziwe i dobre. Owe rozpoznawanie prawdy i dobra, mimo że dokonuje się pod wpływem bytu, powinno być jednak wspomagane przez społeczeństwo. Jak podkreślał Woroniecki, społeczeństwo przez swoją organizację wspiera wysiłki jednostki w coraz doskonalszym rozpoznawaniu prawdy i dobra. Uczestnictwo w życiu społecznym kształtuje szczery stosunek do rzeczywistości - kształtuje obiektywizm w podejściu do rzeczywistości i kwestionuje wszystkie teorie i idee, które są subiektywnymi pomysłami ${ }^{38}$.

\section{Pedagogika tomistyczna wobec wartości}

Istnienie różnych perspektyw w opisie wychowania oznacza brak zgody na jedną koncepcję. Jest on między innymi konsekwencją dostrzeżenia braków ujęcia przeciwnego. W ramach refleksji nad wychowaniem, prowadzonej w duchu tomistycznym, zanegowana została możliwość wychowania przez wartości. Odrzucenie tej koncepcji wynika przede wszystkim z rozumienia wartości jako idei konstrukcji intelektualnych, funkcjonujących w kulturze. Takie ujęcie wartości implikuje ich subiektywizm. Pedagogika tomistyczna sugeruje, że oparcie wychowania na wartościach oznaczałoby wprowadzanie wychowanka w świat subiektywnych idei.

Przyglądając się wypowiedziom na temat wartości, trudno nie stwierdzić, że obiektywizm wartości jest poddawany w wątpliwość. Wprawdzie w wielu kon-

${ }^{36}$ Por. tenże, Studium nad kardynalnq cnota roztropności, Kwartalnik Teologiczny Wileński 1-2 (1923-1924), s. 230; tenże, Metoda i program nauczania teologii moralnej, Lublin 1922, s. 22.

${ }^{37}$ Por. tenże, Wychowanie społeczne i praca społeczna, Prąd 9 (1921), nr 1-2, s. 17-19; tenże, Sprawiedliwość. Najważniejsza jej postać: sprawiedliwość współdzielcza, w: tenże, Wychowanie człowieka. Pisma wybrane, Kraków 1961, s. 155, 162-163, 166; tenże, Rozwój osobistości człowie$k a$, w: tenże, Wychowanie człowieka..., s. 64.

${ }^{38}$ Por. tenże, Studium ..., s. 241; tenże, Katolickość tomizmu, Lublin 1999, s. 20; J. Horowski, Paedagogia perennis. Wychowawcze koncepcje o. Jacka Woronieckiego a kultura przełomu XX i XXI wieku, Toruń 2006, s. 113-114. 
cepcjach filozoficznych i pedagogicznych mówi się o obiektywnych wartościach, co stanowi odwołanie do materialnej etyki wartości, sformułowanej przez Schelera, ale zwolennicy aksjologicznego subiektywizmu mają również silną argumentację na poparcie własnego stanowiska. Swoje poglądy tłumaczą względami (1.) semantycznymi, (2.) epistemologicznymi, (3.) ontologicznymi albo (4.) podmiotowymi. Subiektywizm może więc być uzasadniany (1.) brakiem należytej ścisłości semantycznej w definiowaniu poszczególnych wartości; (2.) niemożliwością poznania wartości, objawiającą się w omylności zarówno poznania zmysłowego, jak i intelektualnego; (3.) monistycznymi koncepcjami rzeczywistości, w których pluralizm wartości staje się złudzeniem, albo wariabilizmem rzeczywistości, odrzucającym istnienie stałych elementów i właściwości bytu; czy wreszcie (4.) uznaniem człowieka za kreatora rzeczywistości, co przy założeniu zróżnicowania ludzi i ich sytuacji życiowych wyklucza obiektywny i uniwersalny charakter sądu aksjologicznego ${ }^{39}$. Przytoczona powyżej argumentacja wydaje się być pod pewnym względem bliska Gogaczowi. Mówiąc o wartościach, zaprzeczył on bowiem ich istnieniu - określił je właśnie jako konstrukcje intelektualne, których subiektywny charakter nie pozostawia watpliwości ${ }^{40}$.

Zauważyć ponadto należy, że przekonanie o obiektywizmie wartości, przekazywane w ramach procesu wychowawczego, narażone jest na dekonstrukcję na poziomie kultury. Subiektywizm miał bowiem swoich zwolenników wśród wielkich współczesnych myślicieli, którzy wywarli znaczący wpływ na kształt obecnej kultury. Należeli do nich na przykład egzystencjaliści, głoszący, że wszystko, co trwałe, m.in. wartości, jest wymysłem. Jedyną pewną rzeczą jest istnienie z jego troską, trwogą i grożącą wciąż śmiercią ${ }^{41}$. Według Heideggera, wszelkie wartościowanie stanowi subiektywizację, więc upieranie się przy obiektywizmie wartości nie ma żadnego fundamentu ${ }^{42}$. Heidegger, zdaniem Tischnera, wyciagnął ostateczne konsekwencje z koncepcji Schelera. Stwierdził bowiem, że najbardziej pierwotne poznanie świata ma charakter emocjonalny i niespostrzeżeniowy ${ }^{43}$.

Zwolennicy obiektywizmu wartości bronią swojego stanowiska, mówiąc, że wartości są nie tyle intelektualnie ujmowane, co doświadczane za pomocą uczuć, więc brak zgody na koncepcję wartości nie musi w praktyce oznaczać ich względności. Z jednej strony, trudno nie przyznać racji temu argumentowi, biorąc pod uwagę fakt, że głoszenie subiektywizmu wartości bardzo często u poszczególnych osób idzie w parze z realizacją we własnym życiu wartości powszechnie uznawanych za pozytywne, ale z drugiej strony, istnieje wiele przesłanek wska-

${ }^{39}$ Por. S. Kowalczyk, Czlowiek..., s. 133-135.

${ }^{40}$ Por. M. Gogacz, Osoba ..., s. 39.

${ }^{41}$ Por. W. Tatarkiewicz, dz. cyt., t. 3, s. 348-349.

${ }^{42}$ Por. M. Heidegger, List o „,humanizmie”, thum. J. Tischner, w: M. Heidegger, Znaki drogi, Warszawa 1999, s. 300.

${ }^{43}$ Por. J. Tischner, dz. cyt., s. 130. 
zujących, że wartości są tylko subiektywnymi ideami, które utrwalone zostały w kulturze i w ten sposób oddziałują na ludzi. Wniosek taki można sformułować, przyglądając się błędom, jakie popełniają osoby kierujące się wartościami. Za przykład może służyć działalność charytatywna. Wielu ludzi postrzega pomoc uboższym, szczególnie dzieciom, jako istotną wartość. Działania podejmowane przez te osoby osiagają w większości przypadków pozytywny skutek, ale część z nich prowadzi do ukształtowania dorosłych ludzi permanentnie oczekujących pomocy od innych, a nie takich, którzy próbują samodzielnie zaradzić swoim potrzebom. W działalności charytatywnej konieczne są więc nie tylko wartości, ale przede wszystkim gruntowna wiedza o rzeczywistości wychowania, która będzie prowadziła do roztropnych działań, a w konsekwencji do najbardziej pełnego rozwoju tych, których otacza się opieką. Wartość ludzkiego działania nie wynika $\mathrm{z}$ intencji podmiotu (jego nakierowania na wartości), ale przede wszystkim ze skutku tego działania. Powyższy przykład wskazuje, że wartość nie ma związku z rzeczywistością. Jest jedynie idea, która na dodatek może przyćmić konkretnemu człowiekowi rozsądną ocenę sytuacji, jeżeli ten będzie mocno skupiony na realizacji wartości. Człowiekowi do dobrego działania potrzebna jest przede wszystkim sprawność rozumu, tak aby posiadł umiejętność analizowania sytuacji i podejmowania roztropnych decyzji. Słuszne wydają się więc twierdzenia Gogacza, który w swojej krytyce wartości mówi, iż odwołanie w wychowaniu do wartości sytuuje człowieka w idealizmie, pomijającym realne osoby, a w związku z tym wychowanie do wartości jest zaprzeczeniem zasady mądrości ${ }^{44}$. Marian Nowak, diagnozując przyczyny współczesnego kryzysu filozofii wartości, wyraża podobną myśl, stwierdzając, że aksjologia w wielu przypadkach jest refleksją idealistyczną ${ }^{45}$.

Obok krytyki oparcia wychowania na wartościach, w ramach myśli tomistycznej pojawiają się próby takiego zdefiniowania wartości, które byłoby zgodne z założeniami filozofii klasycznej a także wolne od niebezpieczeństw subiektywizmu. W koncepcji tomistycznej wartość utożsamiana jest z dobrem, a różnica między wartością i dobrem wynika $\mathrm{z}$ aspektu ujęcia bytu. Implikacją takiego stanowiska jest, po pierwsze, stwierdzenie, że nie ma takiego bytu, który nie stanowi żadnej wartości, ani takiej wartości, która nie byłaby jakimś bytem. Wartość nie istnieje poza bytem, ale w samym bycie, należy do transcendentalnych właściwości bytu (przy ograniczeniu się do tego wniosku pojęcia dobro i wartość mogłyby być stosowane zamiennie $)^{46}$. Po drugie, analizowane pojęcia nie są synonimami, ponieważ dobrami są byty same w sobie, a wartościami te właściwości bytów, dzięki którym są one aktualnie pożądane przez kogoś, czyli dzięki którym stanowią cel dążenia ${ }^{47}$. Zaproponowana w filozofii tomistycznej

${ }^{44}$ Por. M. Gogacz, Osoba ..., s. 39.

${ }^{45}$ Por. M. Nowak, Podstawy..., s. 369.

${ }^{46}$ Por. S. Kowalczyk, Człowiek..., s. 131-132; tenże, Podstawy..., s. 144.

${ }^{47}$ Por. J. Herbut, Dobro..., s. 117; M. A. Krappiec, Odzyskać..., s. 328; A. B. Stępien, Aksjologia, s. 24. 
koncepcja wartości unika utożsamiania ich z istniejącymi poza bytem ideami, a więc nie wprowadza obok porządku bytu alternatywnego porządku wartości, a równocześnie uwzględnia fakt, że sama wartość jest związana z intencjonalnymi aktami emocjonalnymi ${ }^{48}$.

Zaproponowane w filozofii tomistycznej rozumienie wartości nie tylko łączy wartość z bytem, ale umożliwia także dowartościowanie poznania intelektualnego w percepcji wartości. Zgodnie z tą koncepcją, doświadczenie aksjologiczne rozumiane jest jako przeżycie, obejmujące wszystkie poziomy ludzkiego bytu i jego władze, rozpoczynając od poziomu somatyczno-biologicznego, a kończąc na władzach psychiczno-zmysłowych, czyli intelekcie, woli, sumieniu, uczuciach wyższych, samoświadomości. Uznanie roli intelektu w procesie poznania wartości nie wyklucza współudziału woli oraz uczuć w ocenie, a następnie w osobistym wyborze tychże wartości. Unika się jednak w ten sposób ekstremum sentymentalizmu. Intelekt pełni rolę niezbędną i kierowniczą w procesie percepcji wartości. Przedmiotem poznania intelektualnego jest bowiem byt. Oprócz poznania dyskursywnego przyjmuje się jednak również poznanie intuicyjne oraz emocjonalne ${ }^{49}$.

\section{Pedagogika wartości wobec pedagogiki tomistycznej}

Krytyka pedagogiki wartości nie oznacza, że można przyjąć bez zastrzeżeń koncepcje, formułowane w ramach pedagogiki tomistycznej. Odrzucenie wartości i odwoływanie się do logiki transcendentaliów w sytuacji, gdy powszechnie dyskutuje się o wartościach, jest niemożliwe. Można powiedzieć, że wartości, niezależnie od ich koncepcji, stały się elementem ludzkiego świata. Bez względu na to, czy człowiek odkrywa obiektywnie istniejące wartości, czy sam subiektywnie wartościuje różne byty, to niewątpliwie posługuje się wartościami w życiu codziennym. Według Tischnera, świat oczyszczony z wartości i zobiektywizowany jest obcy człowiekowi, a obojętność jednostki na wartości wskazuje na kryzys w życiu tego człowieka ${ }^{50}$.

Wartości są potrzebne człowiekowi między innymi dlatego, że pozwalają mu poruszać się w świecie. Jeżeli człowiek chciałby kierować się wskazówkami Gogacza, który sugeruje odwoływanie się w każdej sytuacji do rzeczywistości $i$ badanie jej w celu rozpoznania prawdy, dobra i piękna bytu, człowiekowi prawdopodobnie zabrakłoby czasu jego życia na rozwiązanie wszystkich problemów, z którymi musiałby się zmierzyć. W wielu decyzjach człowiek posługuje się po prostu ideami, kieruje się na wartości, które uznał jako ważne. Jednym z takich terminów jest słowo ekologiczny. Przypisanie tej cechy jakiemuś przedmiotowi

\footnotetext{
${ }^{48}$ Por. M. A. Krapiec, Odzyskać..., s. 330.

${ }^{49}$ Por. S. Kowalczyk, Człowiek..., s. 141-143, 145-148.

${ }^{50}$ Por. J. Tischner, dz. cyt., s. 480.
} 
oznacza posiadanie przez ów przedmiot wysokiej pozytywnej wartości. Ekologiczność wpływa na decyzje o wymiarze społecznym, politycznym i gospodarczym. Niezależnie od ontologicznego statusu owej wartości, stała się ona jedną z głównych wartości kulturowych w kręgu cywilizacji zachodniej i stanowi wyznacznik różnorodnych działań, choć przeciętny człowiek nie próbuje sprawdzać, dlaczego coś jest ekologiczne ${ }^{51}$.

Jednak nie tylko względy praktyczne wskazują na sens pedagogiki wartości, a tym samym określają niemożność ograniczenia się do koncepcji tomistycznych. Przyglądając się rozwojowi człowieka, można dojść do przekonania, że w jego życiu ma miejsce doświadczenie aksjologiczne, którego nie można zanegować, tak jak czyni to tomizm. Doświadczenie aksjologiczne określane jest jako przeżycie, obejmujące całego człowieka, a nie tylko jego poznawcze władze zmysłowe i umysłowe. Nie jest ono jedynie konstatowaniem faktów ze świata materialnozmysłowego, a taką koncepcję doświadczenia sformułował tomizm ${ }^{52}$. Aby zrozumieć słuszność szerszego niż tomistyczne ujęcia doświadczenia, można odwołać się do wspomnianej wcześniej ekologii. W ramach procesów edukacyjnych próbuje się przekazywać dojrzewającemu człowiekowi podstawowe normy etyki ekologicznej, tłumacząc wpływ środowiska przyrodniczego na ludzkie życie. Owe zabiegi pozostają jednak zazwyczaj nieskuteczne ze względu na brak doświadczenia wartości przyrody u młodego człowieka. Doświadcza on przede wszystkim wartości materialnych, a dokładniej ich wpływu na jego życie. Najpierw jest to telefon komórkowy, następnie komputer, samochód. Kryterium zakupu pierwszego samochodu nie ma zazwyczaj nic wspólnego z postulatami etyki ekologicznej. Pożądany model powinien mieć duży silnik, umożliwiający osiąganie możliwie dużych przyspieszeń i prędkości, powinien mieć również grubą rurę wydechową, która sprawi, że pojawienie się samochodu na ulicy zwróci uwagę przechodniów. Podstawowe przeżycia i doświadczenia dojrzewającego człowieka związane są ze światem ludzkich wytworów. Ich wartości nie trzeba uzasadniać, ponieważ młodzi ludzie odczuwająją na co dzień. Efektem tych doświadczeń jest gotowość do życia w świecie od początku do końca zaplanowanym i zbudowanym przez człowieka: w świecie pubów, siłowni, dyskotek. Przyglądając się metodom pracy, wybieranym w szkołach do realizacji ścieżki ekologicznej, można pokusić się o wniosek, że owe metody dają pewną wiedzę, ale nie powodują doświadczenia wartości przyrody. Owo doświadczenie rodzi się podczas wejścia w kontakt z przyrodą - podczas wędrówki przez góry, spaceru w lesie, czy żeglowania na jeziorze. Obejmuje ono nie tylko przeżycia estetyczne, ale także wpływ kontaktu z przyrodą na siebie, swoje zdrowie, samopoczucie, zmiany w świadomości i osobowości. Człowiekowi posiadającemu takie doświadczenie edukacja ekologiczna dostarcza jedynie informacji, jak chronić przyrodę, którą on postrzega jako olbrzymią wartość.

${ }^{51}$ Por. M. M. Bonenberg, Aksjologiczne problemy ekologii, w: M. Gołaszewska (red.), Poznanie i doznanie. Eseje z estetyki ekologii, Kraków 2000, s. 34.

${ }^{52}$ Por. S. Kowalczyk, Człowiek..., s. 142-143. 
Oceniając możliwość wykorzystania koncepcji tomistycznej w wychowaniu, zwrócić należy również uwagę na fakt, że często podchodzi się do niej wybiórczo. Jacek Woroniecki podkreślał, że w sercu pedagogiki tomistycznej znajduje się zagadnienie sprawności, które kształtowane jest poprzez czyn człowieka, czyli poprzez akt rozumny i wolny ${ }^{53}$. W praktyce tomizm bardzo szybko przechodzi od mówienia o prawdzie do formułowania powinności. Trudności w określeniu, jak motywować człowieka do dobrych czynów i powodować jego doświadczenie prawdy i dobra, zastępuje się stwierdzeniem, co jest prawdziwe i dobre oraz jak należy postępować. Prawda jest więc dogmatyzowana i w takiej formie przekazywana innym. Implikacją tej postawy jest zakwestionowanie autonomii świata i wolności człowieka. Nie ustrzegł się jej sam Woroniecki i to w tak delikatnej kwestii, jak religia. Mówiąc o nadrzędnym celu działań człowieka, stwierdził że jest nim wieczne zjednoczenie z Bogiem, największym i nieskończonym dobrem, zawierajacym $w$ sobie spotęgowane do nieskończoności wszelka prawdę, dobro i piękno, w znikomych ilościach rozsiane po świecie ${ }^{54}$. Jego zdaniem, w ludzkim działaniu cel jest czymś danym. Zadaniem człowieka jest więc jedynie znalezienie środków, za pomocą których zostanie on zrealizowany ${ }^{55}$. Sugerował również, że zjednoczenie z Bogiem powinno być realizowane zarówno w życiu jednostek, jak i społeczności ${ }^{56}$ i w związku z tym za misję Kościoła uważał zarządzanie ziemską społecznością, która, według niego, idealny stan osiaga w zjednoczeniu Kościoła i państwa ${ }^{57}$. W pedagogice religijnej prawda, że celem ludzkiego życia jest zjednoczenie z Bogiem, nie pozostawia wątpliwości, jednak równie mocno podkreśla się, że odkrywanie Boga musi dokonywać się w wolności. Jeżeli religia jest narzucana człowiekowi, bardzo często nie dochodzi on do autentycznej wiary, ale przejmuje czysto zewnętrzną religijność. Wychowanie, nawet religijne, w którym akcent zostanie położony na prawdę, przestaje być więc wychowaniem, a staje się moralizowaniem lub tresurą.

Porównując pedagogikę wartości z pedagogiką tomistyczną, można odnieść wrażenie, że pozostawia ona człowiekowi większą płaszczyznę wolności i dba o to, by każde działanie miało wewnętrzny fundament. W jej ramach podkreśla się bowiem, że działanie skierowane na wartości musi zostać poprzedzone introcepcją wartości. Ich pojawienie się jest z kolei konsekwencją przeżycia, w którym znaczącą rolę odgrywają uczucia. Jeżeli człowiek nie działa zgodnie z jaki-

${ }^{53}$ Por. J. Woroniecki, Program integralnej pedagogiki katolickiej, Ateneum Kapłańskie 47 (1947), s. 166-167; tenże, Metoda..., s. 72; tenże, Nawyk..., s. 18, 26-28; tenże, Rozwój..., s. $75-77$.

${ }^{54}$ tenże, Katolicka ..., dz. cyt., t. I, s. 80.

${ }^{55}$ Por. tamże, t. II/1, s. 21.

${ }^{56}$ Por. tenże, Kościól i państwo (Zagadnienie układu ich stosunków), Wiadomości duszpasterskie 2 (1946), nr 7, s. 3.

${ }^{57}$ Por. tenże, Konkordat czy rozdziat, Rok Polski 3 (1918), nr 6, s. 352-361; tenże, Nacjonalizm a katolicyzm, w: Nacjonalizm a katolicyzm. Opinie biskupów, uczonych, polityków i publicystów wspótczesnych, Poznań 1927, s. 102. 
miś wartościami, można przypuszczać, że nie stały się one treścią jego przeżycia i fundamentem jego osobowości. Poza tym, wartości wyższe nie narzucają się człowiekowi z taką oczywistością jak materialne i przez to, jak pisał Tischner, w myśleniu wedlug wartości istnieje wolność - nic nie zmusza człowieka do przyjęcia wartości ${ }^{58}$.

\section{Zakończenie}

Filozofia wartości i filozofia tomistyczna to dwa różne sposoby opisu świata, budujące odmienne fundamenty dla koncepcji pedagogicznych. Nie pozostawia wątpliwości fakt istnienia między nimi konfliktu, objawiającego się w zarzutach stawianych przeciwnym stanowiskom, chociaż zauważalne są również próby zbliżenia i łączenia przeciwnych koncepcji. Prowadzone w niniejszym artykule rozważania nie wskazały, która z propozycji precyzyjniej ujmuje rzeczywistość wychowania. Każda wnosi wiele do wiedzy pedagogicznej, ale każda zawiera też określone braki. Trudno więc w tym miejscu opowiadać się po którejkolwiek stronie. Różne a nawet sprzeczne stanowiska są jednak pewnym bogactwem. Można powiedzieć, że są one różnymi spojrzeniami, które uzupełniając się przybliżają do zrozumienia rzeczywistości wychowawczej. Zaletą tomizmu jest wiązanie rozwoju człowieka z odkrywaniem bytu, przybliżaniem się do bytu. Filozofia ta wskazuje, że współczesny subiektywizm w wychowaniu może być przezwyciężony nie na drodze dyskusji, ale na drodze zetknięcia wychowanka z konkretną rzeczywistością. Filozofia wartości uzmysławia z kolei, że doświadczenie rzeczywistości nie jest tym samym co poznanie rzeczywistości. Jest bowiem subiektywnym ujęciem rzeczywistości, dokonującym się na drodze przeżycia. Uzależniając realizację wartości od doświadczenia wartości, wskazuje ponadto, że w wychowaniu nie można narzucać dojrzewającej osobie określonych zachowań, postaw, ponieważ takie działania nie prowadzą do autentycznego, integralnego rozwoju. Może więc na terenie pedagogiki należy uznać istnienie odmiennych koncepcji, odsłaniających z różnych perspektyw rzeczywistość wychowania, a tym samym przybliżających do lepszego zrozumienia tej rzeczywistości?

\section{Die thomistische Pädagogik angesichts der Wertepädagogik (Zusammenfassung)}

Das Problem der Werte spielt in der Pädagogik eine wichtige Rolle, weil Axiologie eine Grundlage der Zielbestimmung schafft. Das gegenwärtige Interesse am Thema der Werte in der Erziehung steht im Zusammenhang mit den Problemen, die in der postmodernistischen Kultur erscheinen. Trotz der allgemeinen Werteaufnahme, ist die Rezeption

${ }^{58}$ Por. J. Tischner, dz. cyt., s. 481-482. 
der Werte in der philosophischen Pädagogik nicht eindeutig. Personalistische Pädagogik antwortet auf die Frage, was das Wert ist, und zeigt, wie die Werte den Jugendlichen vermitteln. Die thomistische Pädagogik stellt dagegen fest, dass die Werte nur Ideen sind und die Werterziehung zum Subjektivismus führt. Nach dieser pädagogischen Konzeption beeinflusst stark die Wirklichkeit eine Entwicklung junges Menschen. Sie wirkt auf ihn durch ihre transzendentale Eigenschaften, wie Wahrheit, Güte, Schönheit ein. Die Analyse beider Konzeptionen zeigt, dass einzelne Begriffe sowohl Vor- als auch Nachteile haben. Der Autor entscheidet nicht, welche Konzeption besser ist, aber darstellt, wie sie zum Verstehen des Erziehungsprozesses beitragen. 